\title{
The Use of Bilingual Dictionaries by Foreign Language Learners
}

\author{
Doa'a Al-Momani \\ Princess Rahma College, Al-Balqa Applied University, Al-Salt, Jordan
}

\begin{abstract}
Bilingual dictionaries form good resources for language learners in general, and for foreign language learners in particular. This study mainly examines the strategies employed by FL learners when they use bilingual dictionaries through performing a 10-item translation task. The sample of the present study consists of 25 highlevel students, and 25 low- level students enrolled in graduate studies at Al-Balqa Applied University in Jordan. The results of the present study show that high-level of language development learners tended to employ strategies based on the semantic meanings rather than merely lexical forms. In addition, most of them were somehow less likely to consult a dictionary if the meaning of the original word was easy or they knew a possible semantic equivalent. Low level students, on the other hand, tended to employ strategies based on the lexical form, and in certain cases looked for the first word in the dictionary entry as an equivalent. The findings of the present study support Vygotsky (1978) claim that foreign language learners developmental process moves from being object-regulated to, eventually, being self-regulated.
\end{abstract}

Keywords: bilingual, bilingual dictionaries, foreign language learners

DOI: $10.7176 / J L L L / 55-09$

Publication date: April $30^{\text {th }} 2019$

\section{Introduction}

Dictionaries have provided new opportunities for self-directed learning. One type of these tools is bilingual dictionaries that enhance language learning both within and outside the classroom. In fact, bilingual dictionaries are and always have been very useful tools for language learners. Over the past twenty years or so, great improvements have been made in both the range and quality of information they provide. Accordingly, FL educators must address the use of bilingual dictionaries by FL learners and understand how their language learning and the educators' own teaching may benefit from such tools.

The existing studies on dictionary use in FL learning mainly focused on the advantages of using dictionaries for vocabulary acquisition in reading and writing tasks (Chun, 2001; Lan, 2005; Laufer \& Hill, 2000, among others). This study aims to uncover university-level FL learners' use of bilingual dictionaries in FL learning in performing a translation task and thereby reveal the pedagogical implications of the use of bilingual dictionary to either facilitate self-directed learning or complement classroom-based learning.

\section{Literature Review}

When examining bilingual dictionaries, it is important to first identify what is considered a dictionary and what general functions bilingual dictionaries serve in FL learning. Dictionary use has been a widely explored topic for the purpose of both first language (L1) and second language (L2) learning (Lew, 2011). While Miller (1999) acknowledges that dictionaries provide a wealth of important information about a word, he cautions that "dictionary definitions are deliberately decontextualized" (p.10). McAlpine and Myles (2003) clarify the role of the dictionary in basic language learning: to assist learners in broadening their vocabulary knowledge and understanding of common grammatical errors. Indeed, findings from research studies ( Knight, 1994; Luppescu \& Davy, 1993) suggest that dictionary use is beneficial for L2 learners' vocabulary expansion and for eventual reading comprehension. In particular, dictionary use helps learners build form-meaning connections.

Other researchers ( Gonzalez, 1999; Lew, 2011) stress the influence of learners' L2 proficiency and their dictionary use strategies on their successful use of dictionaries. Higher-proficiency learners tend to employ a wider variety of strategies, and they seek semantic meanings rather than merely lexical forms and meanings. Thus, in FL education, emphasis should also be placed on appropriate training in how to use dictionaries to maximize language development. In addition, Prichard (2008) found that L2 readers at lower proficiency levels lack efficient reading strategies and look up a large number of words that are not central to deciphering the central meaning of texts in the target language.

From a theoretical perspective (Lantolf \& Thorne, 2006; Vygotsky, 1978), the L2 learner's developmental process moves from being object-regulated (learner's language proficiency is influenced by the object used), to being other-regulated (learner's language behavior is controlled by others), to, eventually, being self-regulated (learners know what to do with and how to use language to achieve personal and social purposes). Therefore, skillful use of dictionaries is one of the indicators of FL learners' self-regulation and consequently of successful language development (Elola, Rodríguez-García, \& Winfrey, 2008). Most empirical studies have focused on learners' use of dictionaries for vocabulary learning. Few studies have investigated whether and how FL learners 
use bilingual dictionaries, and the strategies of using dictionaries to support translation tasks. Only with appropriate understanding of learners' current use of bilingual dictionaries will FL educators be able to provide helpful guidance to enhance the use of the tools.

\section{Methodology}

The sample of the present study consisted of 50 English as a Foreign language learners (EFLL) enrolled at AlBalqa Applied university. The students were then divided into two groups depending on the number of courses they took at the university. The first group consisted of 25 university students who are in their first year of higher education and failed in the English Proficiency Test provided by their university; therefore, they have low level of English language development and their experience is limited to what they had been taught in their educational life at school.

The second group, on the other hand, consisted of 25 students who were specializing in English Literature. Therefore, besides what they have already been exposed to during their educational life at school, they have also been exposed to English during their higher education at university. They also successfully ended more than ten courses in English Language and Literature. Thus, we will assume that they have high level of language development.

The students were then asked to translate ten sentences from Arabic to English with the help of a bilingual dictionary where necessary. Each one of the ten sentences included a word that has an equivalent in English language which, in turn, can be confused with certain lexical items that belong to the same semantic field. For instance, the word "Pujour" in sentence (1) means "wages" which can be confused with other words that belong to the same semantic field like salary, pay, payment, compensation, allowance, fee, rent, tip. Similarly, the word "yashhad" , in sentence (2), which means "witness" can be confused with other words like look, gaze, notice, glance, gaze, glimpse, sight, among others (see appendix (1)).

1.Some companies pay higher wages than others.

2.We are here to witness the marriage of two of our best friends.

\section{Results and Discussion}

The collected data of the low and high level language learners were analyzed according to the strategies used by them (either semantics or lexical).

Table (1): Students responses to the translation task

\begin{tabular}{|c|c|c|c|}
\hline & & Low & High \\
\hline 1. & $\begin{array}{l}\text { (qism ala thiea) } \\
\text { Shoe Department } \\
\text { Semantic field: part, section, }\end{array}$ & $\begin{array}{l}0 \% \\
100 \%\end{array}$ & $\begin{array}{l}52 \% \\
48 \% \\
\end{array}$ \\
\hline 2. & $\begin{array}{l}\text { (jus?) } \\
\text { Part }\end{array}$ & $100 \%$ & $100 \%$ \\
\hline 3. & $\begin{array}{l}\text { (Jamal da?im) } \\
\text { Timless beauty } \\
\text { Semantic field: etemal, } \\
\text { Lexical : always, ever, continually, }\end{array}$ & $\begin{array}{l}- \\
72 \% \\
28 \%\end{array}$ & $\begin{array}{l}20 \% \\
80 \% \\
-\end{array}$ \\
\hline 4. & $\begin{array}{l}\text { (yashhad) } \\
\text { Witness } \\
\text { Semantic field } \\
\text { Lexical }\end{array}$ & $\begin{array}{l}8 \% \\
52 \% \\
40 \%\end{array}$ & $\begin{array}{l}40 \% \\
60 \% \\
- \\
\end{array}$ \\
\hline 5. & $\begin{array}{l}\text { (alrjuor) } \\
\text { Wages } \\
\text { Semantic field }\end{array}$ & $\overline{1}-\overline{0} \%$ & $\begin{array}{l}56 \% \\
44 \% \\
\end{array}$ \\
\hline 6. & $\begin{array}{l}\text { (7amlaqa) } \\
\text { Gazed } \\
\text { Semantic field } \\
\text { Lexical }\end{array}$ & $\begin{array}{l}0 \% \\
64 \% \\
36 \%\end{array}$ & $\begin{array}{l}40 \% \\
60 \% \\
-\end{array}$ \\
\hline 7. & $\begin{array}{l}\text { (tarqiig) } \\
\text { To patch } \\
\text { Semantic field }\end{array}$ & $-\overline{100 \%}$ & $\begin{array}{l}56 \% \\
44 \% \\
\end{array}$ \\
\hline 8. & $\begin{array}{l}\text { (Tislah) } \\
\text { Repair } \\
\text { Semantic field } \\
\text { Lexical } \\
\end{array}$ & $\begin{array}{l}20 \% \\
72 \% \\
8 \%\end{array}$ & $\begin{array}{l}52 \% \\
48 \% \\
- \\
\end{array}$ \\
\hline 9. & $\begin{array}{l}\text { (al7aya alrabadyia) } \\
\text { Eternal life } \\
\text { Semantic field }\end{array}$ & $\begin{array}{l}80 \% \\
20 \% \\
\end{array}$ & $\begin{array}{l}72 \% \\
28 \% \\
\end{array}$ \\
\hline 10. & $\begin{array}{l}\text { (alrajir) } \\
\text { The pay } \\
\text { Semantic field }\end{array}$ & $-\overline{100 \%}$ & $\begin{array}{l}24 \% \\
76 \% \\
\end{array}$ \\
\hline
\end{tabular}


Based on table (1), (52\%) of the high level students were able to provide an accurate translation of the word "qism" in the sentence "the clerk in the shoe department saw the thief" without the aid of a bilingual dictionary. While, the rest of them translated the word "qism" as "section", a word that belongs to the same semantic field. On the other hand, none of the low level students was able to provide an accurate translation of this word. In addition, most of them translated this word as "part".

Based on the participants' responses to sentence (2), both groups of students were able to provide an accurate translation of the word "jus?" (part) in (the mermaid lives in the deepest part of the lake) even without using the dictionary.

On the other hand, only $20 \%$ of the high level students were able to provide an accurate translation of the underlined expression in the third sentence "Jamal da?im" (timeless beauty). However, the majority of the two groups $(80 \%$ of the high level group, and $72 \%$ of the low level group) provided translations that belong to the same semantic field as "eternal beauty", and "permanent beauty". The rest of the low level students (28\%) provided inadequate translations as "sustainable beauty" and "always beauty". This in turn proves that low level students based their strategies on lexical forms rather than the semantic one.

Turning now to number (4), (40\%) of the high level students provided an accurate translation of the verb "yashhad" (witness) in the following sentence " We are here to witness the marriage of two of our best friends". The rest of them $(60 \%)$ were also able to provide semantically acceptable words as the word "see", without utilizing a dictionary. On the contrary, just $(8 \%)$ of the low level students were able to provide an adequate translation of this word. In addition, $40 \%$ of them provided inadequate translations as "testify".

Concerning sentence $(5),(56 \%)$ of the high level students translated the word "Pujour" accurately as (wages). The others $(44 \%)$ provided a rendition that belongs to the same semantic field. The whole low level students, on the other hand, rendered this terms as "salaries" or "payment" which also belong to the same semantic field.

However, the participants' responses to sentence (6) reveal that $(36 \%)$ of the low level students rendered the verb "7amlaqa" (gazed) inadequately as "glanced", "focus", or "attend", which in turn proves that low level students usually use lexical base strategies without paying attention to the semantic meaning in context.

Based on our observation of sentence (7) and (8), we can say that many students of the two groups (the low and the high level students) confused the words "tarqii9" (to patch) and "Pisla7" (repair) with other words that are related to the same semantic field as "fix", "reform" and "tinckering".

Sentence (9), on the other hand, reveals that $(80 \%)$ of the low level students rendered the term "al7aya alPabadyi" adequately as (the eternal life). This, in turn, could be due to the fact that the whole students of this group rendered this term by the aid of the bilingual dictionary.

Concerning the last sentence, the majority of the students of the two groups rendered the term "Pajir" which means "the pay" as "salary" or "payment", which are related to the same semantic field.

\section{Conclusion}

In conclusion, it was observed that low level students did not pay attention to the dictionary entry on the whole, but just looked for the first word as an equivalent. However, using a dictionary requires more than just looking up a word in one language and picking the first translation they found. This, in turn, result in poor word choices, which can lead to compositions that are imprecise.

High level learners, on the other hand, do not look up words at random. They appeared to choose an equivalent based on the semantic form. In addition, most of them were somewhat less likely to consult a dictionary if the meaning of the original word was easy or they knew a possible semantic equivalent. Hence, generally advanced students do not need the dictionary so much, while weak ones cannot use it properly.

Low level learners were, in most cases, object regulated since their strategy was mainly based on the lexical form rather than the semantic one. Unlike the low level students, the high level students were self regulated since they based their search on the semantic form.

However, the best way to influence low level learners' dictionary use is through helping them to pass to the other regulated stage. In that, learners have to be guided by their teacher or peers to be able to make use of this useful tool. Teachers can help learners to gain good learning habits. There is tremendous amount of information in a good learner's dictionary. Helping students to get access into that information efficiently is one of the best ways to help them become independent language learners. Finally, students should never be frustrated about using a dictionary; on the contrary, learning to use a dictionary effectively and get the best out of it is an essential language learning skill.

\section{References}

Chun, D. (2001), "L2 reading on the Web: Strategies for accessing information in hypermedia", ComputerAssisted Language Learning 14(5), 367-403.

Elola, I., Rodríguez-García, V., \& Winfrey, K. (2008), "Dictionary use and vocabulary choices in L2 writing”, 
Estudios de Lingüística Inglesa Aplicada 8, 63-89.

Gonzalez, O. (1999), "Building vocabulary: Dictionary consultation and the ESL student", Journal of Adolescent \& Adult Literacy 43(3), 264-270. Available from JSTOR database. (40012150)

Knight, S. (1994), "Dictionary use while reading: The effect on comprehension and vocabulary acquisition for students of different verbal abilities", The Modern Language Journal 78(3), 285-299.

Lan, L. (2005), “The growing prosperity of online dictionaries", English Today 21(3), 16-21.

Lantolf, J. P., \& Thorne, S. L. (2006), "Sociocultural theory and the genesis of second language development". Oxford, UK: Oxford University Press.

Laufer, B., \& Hill, M. (2000), "What lexical information do L2 learners select in a CALL dictionary and how does it affect word retention?” Language Learning \& Technology 3(2), 58-76.

Lew, R. (2011), "Studies in dictionary use: Recent developments”, International Journal of Lexicography 24(1), 1-4.

Luppescu, S., \& Day, R. R. (1993), “Reading, dictionaries, and vocabulary learning”, Language Learning 43, 263-287.

McAlpine, J., \& Myles, J. (2003), "Capturing phraseology in an online dictionary for advanced users of English as a second language: A response to user needs", System 31, 71-84.

Miller, G. A. (1999), “On knowing a word”, Annual Review of Psychology 50, 1-19.

Vygotsky, L. S. (1978). “Mind in society: The development of higher psychological processes”. Cambridge, MA: Harvard University Press.

\section{Appendix}

The employee in the shoe department saw the thief.

The mermaid lives in the deepest part of the lake.

She is one of those women that have a timeless beauty.

We are here to witness the marriage of two of our best friends.

Some companies pay higher wages than others.

$$
\text { 3. 1. تُاهد الموظف من قسم الاحذية اللص. انها احدى النساء اللواتي يتمتعن بجمال دائُ. }
$$$$
\text { 4. نحن هنا اليو لنشهيد \واج اثثين من أعز اصدقائنا. }
$$

The children gazed at the little puppets dancing in the air.

I learned a new way to patch clothes.

$$
\text { 5. تقوَ] بعض الثركات بدفع اجور أعلى من غير ها. }
$$$$
\text { 7. تعلمت طريقة جديدة لترقيع الملابس. }
$$

His job involves making minor repairs on all the machines

We live in this world that will lead us to the eternal life.

The pay in the private sector is much better than in the public one. 